\title{
The pharmacokinetics and pharmacodynamics of perindopril in patients with hepatic cirrhosis
}

\author{
H. H. TSAI, K. R. LEES, C. W. HOWDEN \& J. L. REID \\ Unversity Department of Materia Medica, Stobhill General Hospital, Glasgow G21 3UW
}

1 Perindopril, a new ACE inhibitor, is a prodrug requiring conversion into its active form perindoprilat by hydrolysis in the liver.

2 The pharmacodynamics and pharmacokinetics of perindopril (8 $\mathrm{mg}$ oral) and perindoprilat ( $2 \mathrm{mg}$ intravenously) were studied in a double-blind randomised crossover study in a group of patients with compensated biopsy-proven hepatic cirrhosis.

3 Blood pressure and heart rate responses were similar after the two routes of administration as were plasma renin activity and aldosterone levels following dosing.

4 The AUC of perindoprilat after oral administration of perindopril represented $46 \pm$ $4 \%$ of the total AUC of perindopril and its metabolite when expressed in molar terms. Comparison with the AUC of perindoprilat after its intravenous administration suggested that $30 \pm 6 \%$ of the oral dose of perindopril was converted to its active metabolite.

5 The findings are comparable with those in healthy subjects. It appears that the presence of relatively mild hepatic cirrhosis does not significantly alter the pharmacokinetics of perindopril.

\section{Keywords pharmacokinetics pharmacodynamics perindopril ACE inhibitor cirrhosis}

\section{Introduction}

The angiotensin converting enzyme (ACE) inhibitors are increasingly used with therapeutic benefit in patients with hypertension or heart failure. Perindopril is an ACE inhibitor which has been studied in young healthy subjects (Ajayi et al., 1986; Bussien et al., 1986; Lees \& Reid, 1987a) and in patients with essential hypertension (Lees \& Reid, 1987b). It is an ester pro-drug and has to be converted by de-esterification to its active form, perindoprilat. In man, there is evidence to suggest that this conversion occurs in the liver (Tocco et al., 1982). Patients with impaired hepatic function might, therefore, be expected to show altered pharmacokinetics and pharmacodynamics. There is evidence to suggest that cirrhotics have exaggerated responses to captopril (Pariente et al., 1985). To date no information exists on the bioavailability of perindoprilat after oral administration of perindopril in patients with hepatic impairment. This study describes the pharmacokinetics of the drug in cirrhotic patients and assesses pharmacodynamic responses by measurement of blood pressure and $A C E$ inhibition.

\section{Methods}

\section{Patients}

Eight patients with stable, compensated, biopsyproven hepatic cirrhosis were recruited. Screening was performed by history, physical examination, 12-lead resting electrocardiogram and routine laboratory investigations of full count, serum ferritin, prothrombin time, biochemistry, HBsAg and urinalysis for blood, protein, glucose, ketones and $24 \mathrm{~h}$ urine collection for creatinine 
clearance, sodium and potassium excretion. Written informed consent was obtained from all subjects and the study was approved by the Research and Ethics Committee of Stobhill General Hospital.

The aetiology, hepatic histology, severity of hepatic disease by Childs Grade (with Pugh score modification) and other demographic data are displayed on Tables 1 and 2 . None of the patients was encephalopathic or had ascites. Three patients had oesophageal varices (numbers 1, 2 and 8).

Only three patients were on prior drug therapy, and in these subjects all drugs including diuretics were withdrawn for at least 1 week before
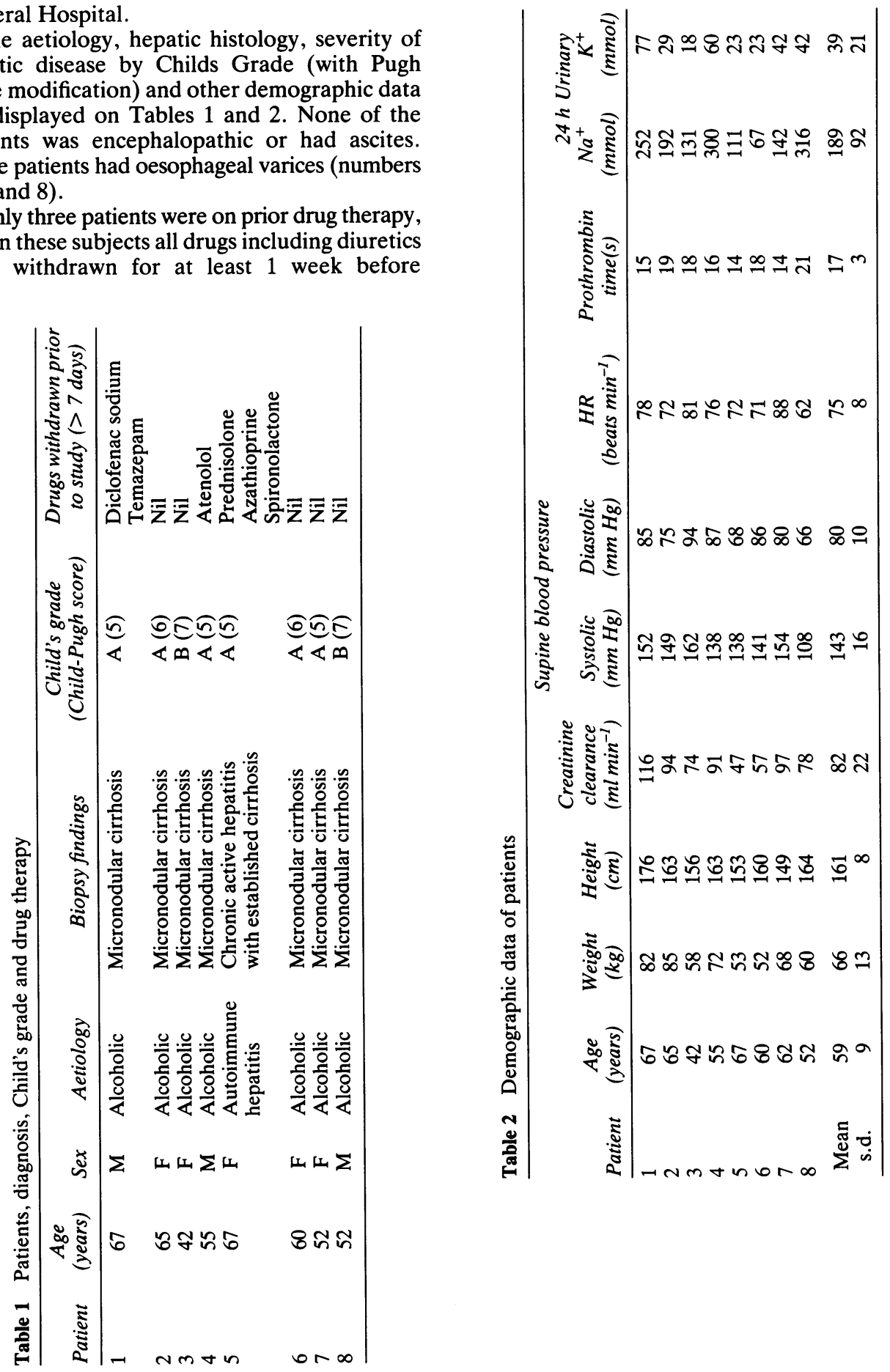
commencement of the study. All patients abstained from alcohol as assessed by direct questioning for at least 1 week before and for the duration of the study. All were normotensive and, apart from subject 5 , had normal renal function. No salt restriction was imposed throughout the study. One patient (number 3) completed the first study period (oral) but withdrew consent for the second period (i.v.) for personal reasons unrelated to the drug or the study.

\section{Study design}

The study was of a double-blind, randomised, crossover design. Since Lees et al. (1988) have reported the systemic availability of the active drug perindoprilat to be $20-30 \%$, we chose to compare $8 \mathrm{mg}$ of oral perindopril with $2 \mathrm{mg}$ of perindoprilat i.v. There were two study periods at least 2 weeks apart. Patients were given either $8 \mathrm{mg}$ of oral perindopril with intravenous vehicle (normal saline) over $2 \mathrm{~h}$, or oral placebo and $2 \mathrm{mg}$ of intravenous perindoprilat over $2 \mathrm{~h}$.

On the study day, patients arrived after an overnight fast at the Clinical Pharmacology Research Unit at $08.30 \mathrm{~h}$. Intravenous cannulae were inserted into each forearm - one for venous sampling, the other for drug/placebo infusion. Patients lay supine for $30 \mathrm{~min}$ after emptying their bladders before commencement of the study. Lunch was provided $4 \mathrm{~h}$ into the study and an evening meal after $8 \mathrm{~h}$.

Blood pressure and heart rate were measured in triplicate by a Sentron semiautomatic sphygmomanometer (Bard Biomedical) (Johnson \& Kerr, 1986) baseline and half-hourly for $8 \mathrm{~h}$ and at 12 and $24 \mathrm{~h}$ post dosing. Blood was sampled for plasma ACE activity and drug concentrations pre-dosing and at the following times after dosing: $5,10,15,20,30,45,60,75,90,105$, $120,135,150,165,180 \mathrm{~min}$ and $3.5,4,5,6,7,8$, $9,10,11,12,24,48,72$ and $96 \mathrm{~h}$. On each occasion blood was collected into lithium heparin tubes, the plasma was separated immediately and stored at $-20^{\circ} \mathrm{C}$. Additional samples for the measurement of plasma renin activity and aldosterone were taken pre-dosing and 2, 4, 6, 8, 24 and $48 \mathrm{~h}$ after dosing. Urine was collected over the following periods and an aliquot retained for perindoprilat assay: $0-2,2-4,4-6,6-8,8-12,12-$ $24,24-48,48-72$ and $72-96 \mathrm{~h}$.

\section{Laboratory methods}

i. Plasma angiotensin converting enzyme activity Plasma angiotensin converting enzyme activity was assayed by measuring the rate of generation of hippuric acid in an incubation mixture containing plasma and hippuryl-histidyl-leucine (Cushman \& Cheung, 1971). Hippuric acid was measured by high pressure liquid chromatography as described by Chiknas (1979). Interand intra-assay coefficients of variation were $6.1 \%$ and $2.3 \%$, respectively and the limit of detection was $0.5 \mathrm{Eu} \mathrm{l}^{-1}$. Samples were assayed within 4 weeks of collection. The normal range for our laboratory is 15.3 to $26.9 \mathrm{Eu} \mathrm{l}^{-1}(95 \%$ confidence interval).

ii. Plasma renin activity Plasma renin activity was determined by specific radioimmunoassay of angiotensin I formed upon cleavage by renin of its substrate angiotensinogen (Derkx et al., 1979). The limit of detection of the assay was 0.1 ngAI ml ${ }^{-1} \mathrm{~h}^{-1}$ and the inter- and intra-assay coefficients of variation were $7 \%$ and $5.5 \%$, respectively.

iii. Plasma aldosterone Plasma aldosterone concentrations were measured by a direct radioimmunoassay using the method of McKenzie et al. (1974). The limit of the assay was $10 \mathrm{pg} \mathrm{ml}^{-1}$ and the inter- and intra-assay coefficients of variation were $11 \%$ and $7.3 \%$, respectively.

iv. Drug analysis Plasma and urinary perindoprilat were analysed by a radioenzymatic assay. Hippuryl-histidyl-leucine containing ${ }^{14} \mathrm{C}$ (Amersham International) was added to the samples which were incubated in rabbit plasma. The generated hippurate was counted in a Packard Tricarb Scintillation counter. Plasma perindopril was first hydrolysed by incubation in pooled rat sera and then analysed as for perindoprilat. The limit of detection of the assay was $0.75 \mathrm{ng} \mathrm{ml}^{-1}$ and the inter- and intra-assay coefficients of variation were $7 \%$ and $5 \%$, respectively at $5 \mathrm{ng} \mathrm{ml}^{-1}$ for perindoprilat and $6 \%$ and $6 \%$, respectively for perindopril at $4 \mathrm{ng} \mathrm{ml}^{-1}$.

\section{Statistical and pharmacokinetic analyses}

i. Statistical analysis Repeated measures analysis of variance was employed to compare the two routes of administration for both direct effect and interactions with time, within the seven subjects who completed both study days. The biomedical statistics package, BMD-P2V was used on an ICL 3980 computer. Results are expressed as mean \pm s.d. Blood pressure and heart rate were analysed as absolute values. Plasma angiotensin converting enzyme activity was converted to percentage inhibition of pretreatment values before analysis. Plasma renin and aldosterone data were transformed to 
logarithmic values before analysis in order to normalise their distribution.

ii. Pharmacokinetic analysis The area under the plasma drug concentration-time curve (AUC) was calculated for each dose by the trapezoidal method. To allow for differences in the molecular weights of perindopril and its metabolite perindoprilat, the doses were all calculated in molar terms. AUCs were calculated separately for perindoprilat following intravenous administration of perindoprilat and for perindoprilat following oral administration of perindopril. Clearance (CL) after intravenous dosing was derived from Dose/AUC. The availability of perindoprilat after oral dosing of perindopril was calculated from:

Availability of perindoprilat $=$

$\frac{\text { Dose iv (perindoprilat) }}{\text { Dose oral (perindopril) }} \times \frac{\mathrm{AUC}_{\text {oral }} \text { (perindoprilat) }}{\mathrm{AUC}_{\mathrm{iv}} \text { (perindoprilat) }}$

The maximum observed concentrations of perindoprilat $\left(C_{\max }\right)$ after oral and intravenous dosing were noted as was the time to maximum concentration $\left(t_{\max }\right)$.

The total cumulative recovery of perindoprilat in urine after both intravenous perindoprilat and oral perindopril administration was calculated from urine volumes and drug concentrations. Renal recovery was expressed as the ratio of cumulative excretion up to $96 \mathrm{~h}$ to the dose administered. The renal clearance of drug was estimated from cumulative recovery/AUC. This was calculated separately for oral and intravenous administration.

\section{Results}

\section{Adverse reactions}

No major adverse reactions were noted. One patient experienced mild headache after oral dosing and another had a substantial fall in erect systolic blood pressure from $144 \mathrm{~mm} \mathrm{Hg}$ to 79 $\mathrm{mm} \mathrm{Hg}$ after intravenous dosing and a similar fall after oral dosing. She remained asymptomatic throughout.

\section{Blood pressure and heart rate}

Mean supine and erect systolic blood pressures both fell after administration of drug. The mean maximum fall of supine systolic blood pressure was $32 \pm 16 \mathrm{~mm} \mathrm{Hg}$ after intravenous perindoprilat and $46 \pm 23 \mathrm{~mm} \mathrm{Hg}$ after oral perindopril. The differences were not statistically significant.

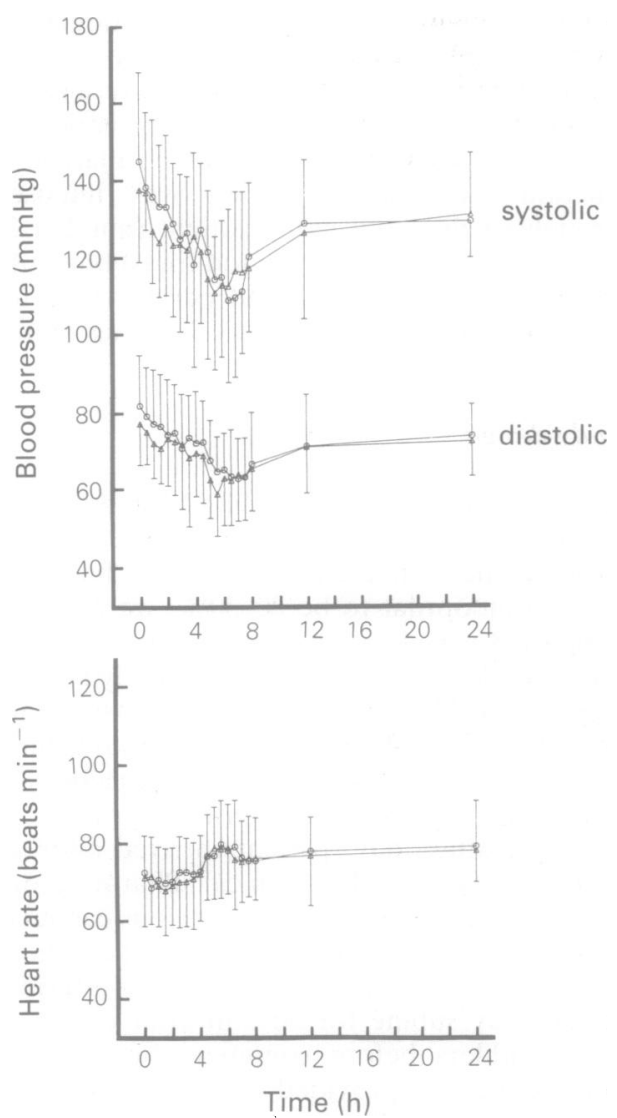

Figure 1 Supine blood pressures and heart rates (mean \pm s.d.) following $8 \mathrm{mg}$ of oral perindopril $(O)$ and $2 \mathrm{mg}$ of intravenous perindoprilat $(\triangle)$.

The mean maximum fall of erect systolic pressure was $41 \pm 15 \mathrm{~mm} \mathrm{Hg}$ and $41 \pm 17 \mathrm{~mm} \mathrm{Hg}$ for intravenous and oral routes, respectively. The mean maximum fall of supine diastolic blood pressure was $22 \pm 9 \mathrm{~mm} \mathrm{Hg}$ for both routes of administration and the mean maximum fall of erect diastolic pressure was $22 \pm 12 \mathrm{~mm} \mathrm{Hg}$ for intravenous and $23 \pm 9 \mathrm{~mm} \mathrm{Hg}$ for oral routes. There was a small insignificant rise in heart rate following treatment (Figure 1). Route of administration did not significantly affect either the blood pressure fall or the time course of blood pressure response. The heart rate response was similar with the two routes of administration of the drug.

\section{Plasma ACE activity}

The maximum inhibition of plasma ACE activity ( \pm s.d.) was $94.5 \pm 2.1 \%$ after intravenous perindoprilat infusion and was achieved towards 
Table 3 Plasma renin activity and aldosterone measurements $(n=7)$

\begin{tabular}{|c|c|c|c|c|c|c|c|}
\hline \multirow{3}{*}{$\frac{\text { Route }}{\text { i.v. }}$} & \multirow{3}{*}{$\begin{array}{c}\begin{array}{c}\text { Time } \\
(h)\end{array} \\
0\end{array}$} & \multicolumn{3}{|c|}{$\operatorname{Renin}\left(n g m l^{-1} h^{-1}\right)$} & \multicolumn{3}{|c|}{ Aldosterone ( $\left.\mathrm{pg} \mathrm{ml}^{-1}\right)$} \\
\hline & & \multirow{2}{*}{$\frac{\text { Geometric mean }}{3.1}$} & \multicolumn{2}{|c|}{$95 \%$ confidence limits } & \multirow{2}{*}{$\frac{\text { Geometric mean }}{82.9}$} & \multicolumn{2}{|c|}{$95 \%$ confidence limits } \\
\hline & & & 1.0 & 10.2 & & 34.9 & 197.0 \\
\hline & 2 & 8.3 & 2.2 & 31.6 & 24.8 & 6.8 & 91.0 \\
\hline & 4 & 8.7 & 1.6 & 48.1 & 27.5 & 9.8 & 77.3 \\
\hline & 6 & 19.2 & 7.3 & 50.0 & 66.9 & 28.1 & 159.4 \\
\hline & 8 & 11.9 & 3.5 & 41.0 & 57.0 & 22.3 & 145.6 \\
\hline & 24 & 4.3 & 1.4 & 13.4 & 93.2 & 44.1 & 196.9 \\
\hline & 48 & 5.8 & 2.6 & 13.1 & 118.3 & 53.7 & 260.8 \\
\hline \multirow[t]{7}{*}{ Oral } & 0 & 2.2 & 0.6 & 8.2 & 59.8 & 34.3 & 104.5 \\
\hline & 2 & 2.3 & 0.8 & 6.6 & 16.9 & 7.8 & 36.6 \\
\hline & 4 & 4.7 & 1.6 & 14.2 & 31.0 & 14.9 & 64.6 \\
\hline & 6 & 12.2 & 5.6 & 26.8 & 30.5 & 12.6 & 74.1 \\
\hline & 8 & 9.7 & 3.2 & 29.0 & 35.1 & 18.4 & 66.9 \\
\hline & 24 & 5.6 & 3.1 & 10.1 & 87.0 & 61.8 & 122.2 \\
\hline & 48 & 4.8 & 2.7 & 8.7 & 113.3 & 59.6 & 215.5 \\
\hline
\end{tabular}

the end of the infusion. The maximum inhibition following oral administration was $89.1 \pm 4.5 \%$ achieved after $3 \mathrm{~h}$.

There was a significantly greater mean ACE inhibition following intravenous compared with oral dosing $(P<0.01)$. The time course also differed as would be expected $(P<0.001)$. There was still inhibition of plasma ACE activity after $96 \mathrm{~h} ; 15.5 \pm 36 \%$ and $41.3 \pm 9.3 \%$ for intravenous and oral routes, respectively.

\section{Plasma renin activity}

There was a significant elevation of plasma renin activity following administration of either form of the drug $(P<0.01)$. There was no difference between the two routes of administration $(P=$ $0.18)$ nor was there any route-time interaction $(P=0.34)$.

The geometric means of the plasma renin activity and $95 \%$ confidence limits are shown in Table 3.

\section{Plasma aldosterone}

There was a tendency for plasma aldosterone to fall after administration of drug and then to recover. The recovery was earlier with intravenous perindoprilat compared with oral perindopril. There was no effect of route of administration $(P=0.36)$ nor was there any significant route-time interaction $(P=0.47)$ on plasma aldosterone levels. The geometric means and $95 \%$ confidence limits are shown in Table 3 .

\section{Pharmacokinetics}

The AUC of perindoprilat after oral administration of perindopril represented $46 \pm 4 \%$ of the total AUC of perindopril and its metabolite when expressed in molar terms. When compared with the AUC of perindoprilat after intravenous administration, $30 \pm 6 \%$ of the oral dose of perindopril appeared to be converted to its active metabolite.

The renal clearance of perindoprilat after intravenous dosing was $58 \pm 17 \mathrm{ml} \mathrm{min}^{-1}$ and 42 $\pm 17 \mathrm{ml} \mathrm{min}^{-1}$ after oral dosing. The total urinary renal recovery of drug after intravenous dosing was $61 \pm 14 \%$.

Individual values of $t_{\max }, C_{\max }$, AUC, clearance $(C L)$ and renal clearance $\left(C_{R}\right)$ after intravenous perindoprilat and oral perindopril are shown in Tables 4 and 5.

\section{Discussion}

ACE inhibitors are being used increasingly for the treatment of hypertension. They have also been found to be beneficial in the treatment of heart failure (Consensus Trial Study Group, 1987). Cardiac failure may be associated with hepatic impairment (Losowsky et al., 1965), albeit dissimilar to hepatic cirrhosis. Perindopril like enalapril, is a prodrug requiring hydrolysis to its active form perindoprilat, a process believed to be carried out in the liver. Our patients had biopsy-proven cirrhosis, in which impaired hepatic metabolism of drugs occurs because of intra- and extra-hepatic shunting as well as hepatocellular failure (Roberts et al., 1979).

In these subjects we found that perindopril lowered systemic blood pressure without significantly altering heart rate. The lack of placebo data meant that blood pressure resonses could not be assessed fully but comparisons with similar studies of young and elderly normal subjects (Lees et al., 1988) show that the fall in blood 
Table 4 Pharmacokinetic data after intravenous perindoprilat

\begin{tabular}{|c|c|c|c|c|}
\hline \multirow[b]{2}{*}{ Patient } & \multicolumn{2}{|c|}{ Perindoprilat } & \multirow[b]{2}{*}{$\begin{array}{c}C L \\
\left(m l \min ^{-1}\right)\end{array}$} & \multirow[b]{2}{*}{$\begin{array}{c}C L_{R} \\
\left(\mathrm{ml} \mathrm{min}^{-1}\right)\end{array}$} \\
\hline & $\begin{array}{c}C_{\max } \\
\left(n g m l^{-1}\right)\end{array}$ & $\begin{array}{c}A U C \\
\left(n g m l^{-1} h\right)\end{array}$ & & \\
\hline 1 & 79 & 300 & 111 & 60 \\
\hline 2 & 22 & 308 & 108 & 60 \\
\hline 3 & - & - & - & - \\
\hline 4 & 67 & 309 & 108 & 41 \\
\hline 5 & 126 & 581 & 57 & 38 \\
\hline 6 & 83 & 333 & 100 & 67 \\
\hline 7 & 94 & 310 & 108 & 89 \\
\hline 8 & 95 & 428 & 78 & 50 \\
\hline Mean & 81 & 367 & 96 & 58 \\
\hline s.d. & 32 & 104 & 20 & 17 \\
\hline
\end{tabular}

$C_{\text {max }}$ - Maximum observed concentration

AUC - Area under the concentration-time curve from 0-96 h $\mathrm{CL}$ - Plasma clearance calculated as dose

$\overline{\mathrm{AUC}}$

$C L_{R}-$ Renal clearance calculated as renal recovery

AUC

Table 5 Pharmacokinetic data after oral perindopril

\begin{tabular}{|c|c|c|c|c|c|c|}
\hline Patient & $\begin{array}{c}t_{\max } \\
(h)\end{array}$ & $\underset{\left(n g m l^{-1}\right)}{C_{\max }}$ & $\begin{array}{l}\text { Perindoprilat } \\
\text { AUC } \\
\left(n g m l^{-1} h\right)\end{array}$ & $\begin{array}{c}C L \\
\left(\mathrm{ml} \mathrm{min}^{-1}\right)\end{array}$ & $\begin{array}{c}C L_{R} \\
\left(\mathrm{ml} \mathrm{min}^{-1}\right)\end{array}$ & $\begin{array}{c}\text { Perindopril } \\
\text { AUC } \\
\left(n g m l^{-1} h\right)\end{array}$ \\
\hline 1 & 2.25 & 25 & 287 & 116 & 39 & 360 \\
\hline 2 & 2.25 & 28 & 259 & 129 & 42 & 314 \\
\hline 3 & 2.25 & 41 & 312 & 107 & 73 & 295 \\
\hline 4 & 4.00 & 23 & 350 & 95 & 38 & 433 \\
\hline 5 & 1.50 & 16 & 411 & 81 & 11 & 601 \\
\hline 6 & 1.50 & 26 & 271 & 123 & 54 & 279 \\
\hline 7 & 1.75 & 47 & 350 & 95 & 39 & 321 \\
\hline 8 & 2.25 & 27 & 328 & 102 & 38 & 413 \\
\hline Mean & 2.34 & 29 & 321 & 106 & 37 & 377 \\
\hline s.d. & 0.74 & 10 & 50 & 16 & 13 & 106 \\
\hline \multicolumn{7}{|c|}{$\begin{array}{l}C_{\max }-\text { Maximum observed concentration } \\
t_{\max } \text { - Time to maximum observed concentration } \\
\text { AUC - Area under the concentration-time curve from } 0-96 \mathrm{~h} \\
\text { CL - Plasma clearance calculated as dose }\end{array}$} \\
\hline
\end{tabular}

pressure in patients with hepatic cirrhosis is similar to the expected blood pressure fall in normal subjects of a similar age.

The effect of the drug on plasma renin activity and aldosterone is similar to that reported previously. Basal plasma renin activity was higher, as would be expected in patients with hepatic disease.

The availability of perindoprilat after oral perindopril in this group of cirrhotic patients was $30 \pm 6 \%$ when expressed in molar terms. A previous study comparing the pharmacokinetics in young and elderly subjects (Lees et al., 1988) reported values of $19 \pm 7 \%$ in the young (mean age $29 \pm 3$ years) and $35 \pm 17 \%$ in the elderly (mean age $71 \pm 3$ years). The patients in this study had a mean age of $59 \pm 9$ years which is in between these young and elderly groups. The value obtained for the availability of the metabolite after oral perindopril was also different between the two groups. It appears that there is an increased availability of perindoprilat following oral perindopril with age. Presence or absence of hepatic cirrhosis did not appear to be contributory.

The reason for this apparent age-related 
phenomenon is not known. There are two possible explanations as to why hepatic disease did not alter the pharmacokinetics of the drug. The liver

\section{References}

Ajayi, A. A., Lees, K. R. \& Reid, J. L. (1986). Effects of angiotensin converting enzyme inhibitor, perindopril, on autonomic reflexes. Eur. J. clin. Pharmac., 30, 177-182.

Bussien, J. P., d'Amore, T. F., Perret, L., Porchet, M., Nussberger, J., Waeber, B. \& Brunner, H. R. (1986). Single and repeated dosing of the converting enzyme inhibitor perindopril to normal subjects. Clin. Pharmac. Ther., 39, 554-558.

Chiknas, S. G. (1979). A liquid chromatographyassisted assay for angiotensin converting enzyme (peptidyl dipeptidase) in serum. Clin. Chem., 25, 1259-1262.

Consensus Trial Study Group (1987). Effects of enalapril on mortality in severe congestive heart failure. Results of the Cooperative North Scandinavian Enalapril Survival Study I (CONSENSUS). New Engl. J. Med., 316, 1429-1435.

Cushman, D. W. \& Cheung, H. S. (1971). Spectrophotometric assay and properties of the angiotensin converting enzyme of rabbit lung. Biochem. Pharmac., 20, 1637-1648.

Derkx, F. H. M., Tan-Tjiong, H. L., Man in't Veld, A. J., Schalekamp, M. P. A. \& Schalekamp, M. A. D. H. (1979). Activation of inactive plasma renin by plasma and tissue kallikreins. Clin. Sci., 57, 351-357.

Farrell, G. C., Cooksley, W. G. E. \& Hart, P. (1978). Drug metabolism in liver disease: identification of patients with impaired hepatic drug metabolism. Gastroenterology, 75, 580.

Johnson, C. J. H. \& Kerr, J. H. (1985). Automatic blood pressure records: a clinical evaluation of five models in adults. Anaesthesia, 40, 471-478.

Lees, K. R. \& Reid, J. L. (1987a). Haemodynamic may not be the site of conversion of the drug or there was sufficient hepatic reserve in this group of cirrhotics. and humoral effects of oral perindopril, an angiotensin converting enzyme inhibitor in man. Br. J. clin. Pharmac., 23, 159-164.

Lees, K. R. \& Reid, J. L. (1987b). The haemodynamic and humoral effects of treatment for one month with the angiotensin converting enzyme inhibitor perindopril in salt replete hypertensive patients. Eur. J. clin. Pharmac., 31, 519-524.

Lees, K. R., Green, S. T. \& Reid, J. L. (1988). Influence of age on the pharmacokinetics and pharmacodynamics of perindopril. Clin. Pharmac. Ther., 44, 418-425.

Lowsowsky, M. S., Ikram, H. \& Snow, H. M. (1965). Liver function in advanced heart disease. Br. Heart J., $27,578$.

McKenzie, J. K. \& Clements, J. A. (1974). Simplified radioimmunoassay for serum aldosterone utilising increased antibody specificity. J. clin. Endocrinol. Metab., 38, 622-627.

Pariente, A. E., Bataille, C., Bercoff, F. \& Lebrec, D. (1985). Acute effects of captopril on systemic and renal haemodynamics and on renal function in cirrhotic patients with ascites. Gastroenterology, 88, 1255-1259.

Roberts, R. K., Bodach, R. A. \& Desmond, P. V. (1979). The influence of liver disease on drug disposition. Clin. Gastroenterol., 8, 105.

Tocco, D. J., De Luna, F. A., Duncan, A. E. W., Vassil, T. C. \& Ulm, E. H. (1982). The physiological disposition and metabolism of enalapril maleate in laboratory animals. Drug Metab. Dispos., 10, 15-19.

(Received 9 June 1988, accepted 3 March 1989) 